\title{
DEFOLIATION BY GRASS GRUB BEETLES IN WAIKATO ORCHARDS
}

\author{
R. EAST, B.E. WILLOUGHBY and M.S. KOLLER
}

Ruakura Soil \& Plant Research Station, MAF, Private Bag, Hamilton

\section{SUMMARY}

Two seasons of monitoring grass grub (Costelytra zealandica) beetle flights and damage to crops such as grapes (Vitis spp) and blueberries (Vaccinium corymbosum) and their shelter belts at the Rukuhia Horticultural Research Area showed that there was a rapid onset of defoliation when the cumulative catch of beetles in sex attractant traps reached $51 \%$ (1981) and 44\% (1982) of the season's total. Defoliation then continued for the remaining 3-4 weeks of the flight season. An insecticide trial comparing seven chemicals (azinphos-methyl, carbaryl, chlorpyrifos, cypermethrin, deltamethrin, lindane and methiocarb) revealed that while all chemicals provided some initial protection, only the synthetic pyrethroids gave a substantial reduction in defoliation for more than 3 days after spraying.

\section{INTRODUCTION}

Grass grub beetles are well known as minor pests in pip and stone fruit orchards through their habit of attacking foliage in spring. This defoliation can be severe in localised areas, especially in orchards which are surrounded by extensive areas of grass grub-infested pasture. In some cases the beetles may arise from within the orchard (e.g. Blank and Olson 1982). The recent rapid expansion of horticulture into pastoral farming areas in the Waikato has been accompanied by a marked increase in reports of serious defoliation of spring growth of blueberries, kiwifruit (Actinidia chinensis) and grape vines, and shelter belts within newly established orchards. This paper reports observations on the occurrence of grass grub beetle damage in relation to flight activity and the prevention of defoliation with insecticides.

\section{METHODS}

Flight activity and defoliation

Grass grub adult flight activity was monitored with sex attractant traps (Henzell $e t$ al 1979) in 1981 and 1982 at the 20 ha Rukuhia Horticultural Research Area and in the surrounding pastureland. Five traps were placed 50 to $100 \mathrm{~m}$ within the Research Area, among 1-year old grape vines and blueberries, and five traps in the surrounding pasture, $50 \mathrm{~m}$ outside the Research Area boundary. From the commencement of flight activity, daily inspections were made of the extent of defoliation by grass grub beetles on grapes, blueberries, kiwifruit and shelter belts at localities throughout the Research Area. Insecticide trial

Eight chemical treatments (Table 1) were tested for their effectiveness in protecting a 1-year old, 1-3 m high shelter belt of hybrid willows (Salix alba $x$ S. matsudana) at the Rukuhia Horticultural Research Area from defoliation by grass grub beetles. Individual plots comprised three adjacent willows within the row. Treatments were applied on 1 November 1982 by spraying to runoff with a handgun and motorised pump. Application rates (Table 1) were based on label recommendations or known insecticidal activity. Wettable powder formulations were applied with a sticker ('Cittowett' added to the spray mix at $0.1 \mathrm{ml} /$ litre). Each treatment was replicated four times in a randomised block design.

Proc. 36th N.Z. Weed and Pest Control Conf. 
The central willow in each plot was inspected daily by the same observer and scored for defoliation on the following scale (approximate levels of defoliation are given in parentheses):

0 - no defoliation.

1 - very slight defoliation (less than $1 \%$ of the leaves showing some defoliation).

2 - slight defoliation (1-5\% of the leaves showing some defoliation with no individual leaves stripped to the midrib).

3 - moderate defoliation (6-20\% of the leaves showing some defoliation with up to $10 \%$ stripped to the midrib).

4 - moderate to severe defoliation $(21-50 \%$ of the leaves showing some defoliation with up to $20 \%$ stripped to the midrib).

5 - severe defoliation (more than $50 \%$ of the leaves showing some defoliation, with up to $40 \%$ stripped to the midrib).

A $30 \times 20 \times 5 \mathrm{~cm}$ water-filled, wirenetting-covered plastic tray was placed beneath the central willow in each plot and inspected daily for grass grub adults.

Bioassays were carried out by picking a $10-15 \mathrm{~cm}$ long twig containing 12-15 undamaged leaves from the central willow in each plot at varying intervals after spraying and placing it on the surface of $5-10 \mathrm{~cm}$ of soil within a flyscreen mesh-covered $15 \times 15 \times 18 \mathrm{~cm}$ plastic pot containing 50 freshly collected grass grub adults. The pots were held overnight in an outdoor insectary. On the following morning assessments were made of defoliation, using the above scale, and the number of beetles affected by the treatment, i.e., the number lying dead or moribund on the soil surface.

\section{Flight activity and defoliation}

\section{RESULTS AND DISCUSSION}

Severe defoliation by grass grub beetles commenced suddenly at the Rukuhia Horticultural Research Area on 7 November 1981 and 3 November 1982, 2-3 weeks after the first flight activity, and continued for the remaining 3-4 weeks of the flight season (Fig. 1). In each year the appearance of severe defoliation was preceded by $1-3$ nights of slight defoliation. Feeding damage was patchily distributed both within the Research Area and within individual crops, with severely defoliated plants often adjacent to undefoliated plants of the same species. On affected plants defoliation was concentrated initially on the uppermost leaves. The lowest part of the plant was the last to be attacked.

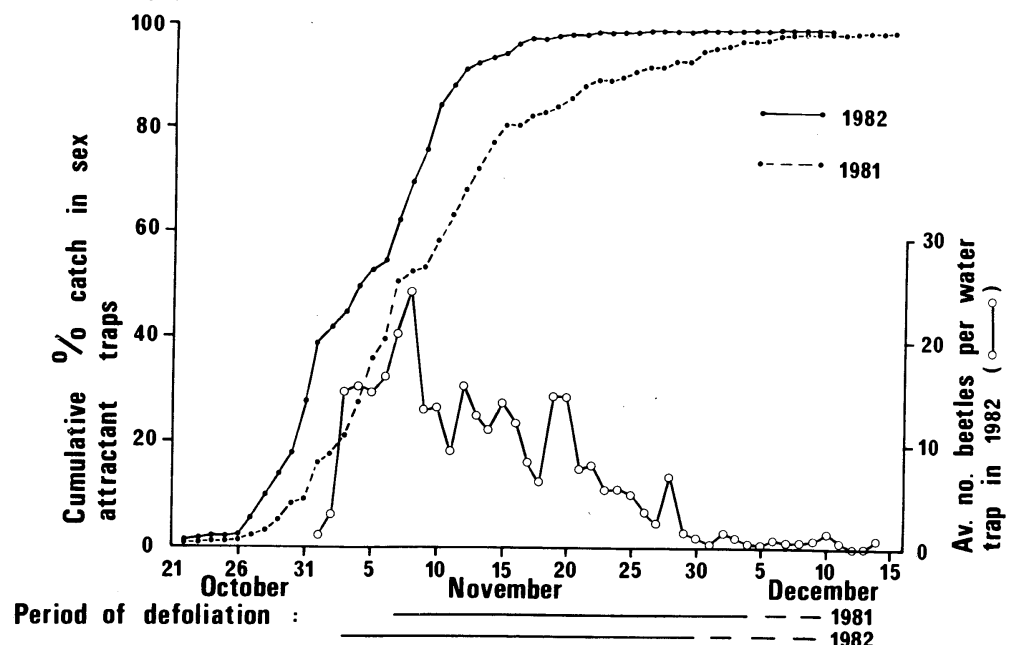

Fig. 1: Grass grub adult flight and feeding activity at the Rukuhia trial site. 
The rapid increase in defoliation is illustrated by the unsprayed controls in the insecticide trial (Table 1), where the mean defoliation score increased ten-fold to the maximum level on the scale used (5.0) between 1 and 4 November 1982. During the subsequent 3 weeks defoliation of the controls increased further to the level where $80-90 \%$ of the leaves showed some defoliation. This particularly severe defoliation may have been due to the willow shelter belt being surrounded by fallow land at the time of the insecticide trial, so that it formed a marked silhouette. Our observations suggest that grass grub adults are attracted to silhouetted trees and shrubs in a similar manner to other scarabaeids (e.g., Tashiro et al 1969).

In the Waikato there are two distinct phases of the grass grub beetles' flight season (Kain 1975). After an initial period when mating activity and oviposition are predominant, the beetles move on to trees and shrubs in the latter part of the flight season, feeding and continuing to mate at night and sheltering in the soil near the base of the tree during the day. At Rukuhia in 1981 and 1982 this change in behaviour occurred suddenly, with a rapid onset of defoliation. Soil sampling before the adult flight season had revealed much lower grass grub populations within the Horticultural Research Area $\left(1-5 / \mathrm{m}^{2}\right)$ than in the surrounding pastures $\left(30-50 / \mathrm{m}^{2}\right)$. However, the sex attractant trap catches in the two areas were very similar both in numbers and seasonal pattern (cf. East et al 1982) and they were therefore averaged. Defoliation commenced when the cumulative catch of the sex attractant traps reached $51 \%$ in 1981 and $44 \%$ in 1982 (Fig. 1).

The catches of the water-filled traps in the insecticide trial did not differ significantly between treatments $(\mathrm{P}>0.10)$. These traps were apparently equally effective at intercepting healthy beetles which were returning to the soil after feeding and those affected by insecticide. The overall average catch provided an indication of the occurrence of feeding activity (Fig. 1.).

TABLE 1: Defoliation of willows in Rukuhia field trial (chemicals applied 1 November 1982).

\begin{tabular}{|c|c|c|c|c|c|c|c|c|}
\hline \multirow[t]{3}{*}{ Chemical } & \multirow{3}{*}{$\begin{array}{c}\text { Rate } \\
\text { (g ai/100 litres) }\end{array}$} & \multicolumn{7}{|c|}{ Mean defoliation score } \\
\hline & & & & & & & & \\
\hline & & $\mathrm{DAS}^{*} 0$ & 1 & 3 & 5 & 7 & 9 & 12 \\
\hline cypermethrin & 10.0 & 0.2 & 0.2 & 1.5 & 2.2 & 2.5 & 3.0 & 4.0 \\
\hline cypermethrin & 5.0 & 0.2 & 0.2 & 1.7 & 2.2 & 3.7 & 3.5 & 4.2 \\
\hline deltamethrin & 1.25 & 0.0 & 0.2 & 1.7 & 3.2 & 4.0 & 4.0 & 4.5 \\
\hline carbaryl & 125.0 & 0.5 & 2.2 & 3.2 & 4.5 & 5.0 & 5.0 & 5.0 \\
\hline methiocarb & 113.0 & 0.5 & 2.0 & 3.0 & 4.2 & 4.7 & 4.7 & 4.7 \\
\hline lindane & 50.0 & 0.0 & 2.5 & 3.7 & 5.0 & 5.0 & 5.0 & 5.0 \\
\hline chlorpyrifos & 25.0 & 0.5 & 2.7 & 4.2 & 4.7 & 4.5 & 5.0 & 5.0 \\
\hline azinphos-methyl & 50.0 & 0.5 & 2.7 & 4.2 & 5.0 & 4.7 & 5.0 & 5.0 \\
\hline control & - & 0.5 & 3.7. & 5.0 & 5.0 & 5.0 & 5.0 & 5.0 \\
\hline
\end{tabular}

* days after spraying

\section{Effects of insecticides on defoliation}

Observations of grape vines and blueberry bushes which received the same chemical treatments in replicated trials at Rukuhia revealed that the effects of insecticides on defoliation observed in the willow trial were general. The synthetic pyrethroids gave better protection against defoliation than the other insecticides tested (Table 1). Analysis of variance of the defoliation scores revealed that the chemicals fell into three significantly different groups $(\mathrm{P}<0.05)$ : cypermethrin (Ripcord $20 \mathrm{EC})$ and deltamethrin (Decis $2.5 \mathrm{EC}$ ) significantly reduced defoliation below the level of the 
controls $(\mathrm{P}<0.05)$ for 5-6 days after treatment $(9$ days for the higher rate of cypermethrin); carbaryl (Ispray Carbaryl 80 WP) and methiocarb (Mesurol 75 WP) significantly reduced defoliation below the controls for 3 days after treatment; lindane (Ispray Lindane $20 \mathrm{EC}$ ), chlorpyrifos (Lorsban $40 \mathrm{EC}$ ) and azinphos-methyl (Gusathion 50 WP) significantly reduced defoliation below the controls for 1 day after treatment.

Similar results are apparent from the bioassays (Table 2). Cypermethrin and deltamethrin gave a significant reduction in defoliation $(P<0.05)$ below the controls for 7 days, carbaryl and methiocarb for 2 days, and lindane, chlorpyrifos and azinphosmethyl on the day of treatment only. The number of beetles affected showed a similar pattern (Table 2), except that some materials continued to show insecticidal activity after they no longer prevented defoliation, e.g., carbaryl and methiocarb 4-10 days after spraying.

TABLE 2: Results of bioassays with willow foliage from Rukuhia field trial. $D=$ mean defoliation score; $M=$ percentage of beetles affected.

\begin{tabular}{|c|c|c|c|c|c|c|c|c|c|c|}
\hline \multirow{2}{*}{$\begin{array}{l}\text { Chemical } \\
\text { (g ai/100 litres) }\end{array}$} & \multicolumn{2}{|c|}{0} & \multicolumn{2}{|c|}{2} & \multicolumn{2}{|c|}{4} & \multicolumn{2}{|c|}{7} & \multicolumn{2}{|c|}{10} \\
\hline & $\mathrm{D}$ & M & $\dot{D}$ & M & D & M & $\mathrm{D}$ & M & $\mathrm{D}$ & M \\
\hline cypermethrin (10) & 0.2 & 43 & 1.0 & 54 & 1.2 & 36 & 1.7 & 33 & 4.0 & 6 \\
\hline cypermethrin (5) & 0.2 & 40 & 1.2 & 26 & 2.5 & 27 & 3.0 & 14 & 4.0 & 4 \\
\hline deltamethrin (1.25) & 1.0 & 38 & 1.7 & 22 & 2.5 & 18 & 2.7 & 12 & 4.7 & 2 \\
\hline carbaryl (125) & 2.2 & 23 & 2.7 & 25 & 4.2 & 38 & 3.7 & 16 & 4.7 & 18 \\
\hline methiocarb (113) & 2.5 & 32 & 3.0 & 24 & 3.5 & 34 & 4.0 & 22 & 4.3 & 26 \\
\hline lindane $(50)$ & 3.0 & 23 & 4.2 & 13 & 4.2 & 12 & 4.7 & 3 & 4.5 & 2 \\
\hline chlorpyrifos (25) & 3.2 & 21 & 3.7 & 19 & 5.0 & 9 & 5.0 & 2 & 4.2 & 2 \\
\hline azinphos-methyl (50) & 3.2 & 20 & 4.0 & 8 & 4.5 & 6 & 4.5 & 2 & 4.2 & 2 \\
\hline control & 4.5 & 3 & 4.7 & 7 & 4.7 & 5 & 4.5 & 2 & 5.0 & 0 \\
\hline
\end{tabular}

* days after spraying

A chemical must knock down or repel beetles before feeding occurs, to prevent defoliation. The superiority of the synthetic pyrethroids over the carbamate and organophosphate insecticides tested reflects their markedly superior contact activity (Holland et al 1981). Other synthetic pyrethroids not included in this study would probably also be effective when applied at the appropriate rate, e.g., permethrin and possibly fenvalerate (Lauren et al 1980). The willow shelter belt insecticide trial was a severe test, since it was attacked by large numbers of grass grub beetles and weather conditions at Rukuhia were favourable for flight (Kelsey 1968) on most nights in November 1982. Under the conditions of this trial at least three or four applications of cypermethrin or deltamethrin at 5 to 9-day intervals would have been necessary to provide complete protection (Fig. 1, Table 1).

A possible drawback in using synthetic pyrethroids is that their use can lead to increases in phytophagous mite populations (Chapman and Penman 1979). Chemicals less effective than synthetic pyrethroids may provide sufficient protection against defoliation by grass grub beetles if beetle attack is not severe, e.g., because unfavourable weather restricts flight during the period of feeding activity, or the plants are able to tolerate defoliation in the spring with little effect on subsequent growth or fruit yield.

REFERENCES

Blank, R.H. and Olson, M.H., 1982. Grass grub adults defoliate tamarillos in North land. Proc. 35th N.Z. Weed and Pest Control Conf.: 27-31 
Chapman, R.B. and Penman, D.R., 1979. Toxicity of synthetic pyrethroid insecticides to phytophagous orchard mites. Proc. 32nd N.Z. Weed and Pest Control Conf.: 240-4

East, R., Henzell, R.F. and Lauren, D.R., 1982. An evaluation of sex attractant traps for monitoring grass grub, Costelytra zealandica, populations (Coleoptera: Scarabaeidae). N.Z. Ent. 7: 262-5

Henzell, R.F., Lauren, D.R. and Cox, N.R., 1979. Monitoring Costelytra zealandica flight with sex attractant traps (Coleoptera: Scarabaeidae). Proc. 2nd Australasian Conf. Grassld. Invert. Ecol.: 125-8

Holland, P.T., Henzell, R.F. and Skinner, R.A., 1981. Insecticides for control of adult grass grub. IV. Comparative activity of insecticides in contact and soil bioassays. Proc. 34th N.Z. Weed and Pest Control Conf.: 239-42

Kain, W.M., 1975. Population dynamics and pest assessment studies of grass grub (Costelytra zealandica (White), Melolonthinae) in the North Island of New Zealand. Ph.D. thesis, Lincoln College.

Kelsey, J.M., 1968. Flight and ground collection records of Costelytra zealandica (White) at a site in Canterbury, New Zealand. N.Z. Jl. Sci. 11: 664-85

Lauren, D.R., Henzell, R.F. and du Toit, G.D.G., 1980. Insecticides for control of adult grass grub, Costelytra zealandica (White). I. Chemical and biological field life of various synthetic pyrethroid formulations. N.Z. Jl. agric. Res. 23: 111-5

Tashiro, H., Gyrisco, G.G., Gambrell, F.L., Fiori, B.J. and Breitfeld, H., 1969. Biology of the European chafer Amphimallon majalis (Coleoptera: Scarabaeidae) in northeastern United States. Bull. New York State Agric. Exp. Stn. 828: 1-71 